\title{
IL-1 Vaccination Is Suitable for Treating Inflammatory Diseases
}

\author{
Eric Assier ${ }^{1,2}$, Natacha Bessis ${ }^{1,2}$, Jean-François Zagury ${ }^{3}$ and \\ Marie-Christophe Boissier ${ }^{1,2,4 *}$
}

${ }^{1}$ UMR 1125 Institut National de la Santé et de la Recherche Médicale, Bobigny, France, ${ }^{2}$ Sorbonne Paris Cité Université Paris 13, Bobigny, France, ${ }^{3}$ EA 4627, CNAM, Paris, France, ${ }^{4}$ Assistance Publique-Hôpitaux de Paris, HUPSSD, Service de Rhumatologie, Bobigny, France

Keywords: IL-1, vaccination, inflammation, chronic disease, cytokines

\section{RELEVANCE OF VACCINATION}

Anti-cytokine therapy associated with immunosuppressive drugs has demonstrated high efficiency in treatment of several autoimmune diseases, including rheumatoid arthritis (RA). Current treatments approved for use in patients are targeting inflammatory cytokines TNF- $\alpha$, IL-1, or IL-6 and more drugs are undergoing clinical evaluation (Semerano et al., 2016a).

Three types of cytokine inhibitors had been developed in RA. The great majority of them is constituted by monoclonal antibodies (mAbs) directed against the cytokine or its receptor. A second category is based on recombinant proteins combining soluble receptors of cytokine stabilized by the Fc domain of IgG1 antibodies. A third type of anti-cytokine drugs is constituted by recombinant receptor antagonist that binds to receptor without induction of signaling.

One common feature of these inhibitors is their high interaction with the cytokine or its receptor

OPEN ACCESS

Edited by:

Francesca Oliviero,

University of Padua, Italy

Reviewed by:

Giulio Cavalli,

Vita-Salute San Raffaele University,

Italy

*Correspondence:

Marie-Christophe Boissier marie-christophe.boissier@aphp.fr

Specialty section:

This article was submitted to Inflammation Pharmacology,

a section of the journal

Frontiers in Pharmacology

Received: 01 December 2016 Accepted: 04 January 2017 Published: 31 January 2017

Citation:

Assier E, Bessis N, Zagury J-F and Boissier M-C (2017) IL-1 Vaccination Is Suitable for Treating Inflammatory

Diseases. Front. Pharmacol. 8:6.

doi: 10.3389/fphar.2017.00006 that could induce excessive inhibition and some drawback for development. A common side effect is the production, after treatment, of anti-drug antibodies that result in frequent primary or secondary resistance to the treatment. In addition all these drugs have limited effect in the majority of cases; for instance in rheumatoid arthritis, targeted treatments induce 6-month remission in 25$30 \%$ patients, and a response different of remission in $50 \%$ cases. Partial resistance represents, in the first 6 months, 70\% of patients. Furthermore, available anti-cytokine drugs are expensive and need frequent long-term administration.

In this context, a novel type of anti-cytokine drugs based on vaccination is emerging (Semerano et al., 2012). In this case, therapeutic antibodies are produced by the individual itself. This approach has the advantage to generate antibodies that are well-tolerated because of the absence of xenogenic epitopes.

The saga of anti-TNF- $\alpha$ vaccination recapitulates the different steps of such strategy. Several vaccination approaches were conducted in parallel to develop a vaccine against TNF- $\alpha$. In order to induce a B cell response, DNA vaccination, introduction of a foreign Th cell epitope and coupling TNF- $\alpha$ (or peptides of TNF- $\alpha$ ) with carrier proteins were developed in animal models of RA.

A vaccine (TNF-K) constituted by coupling human TNF- $\alpha$ to the carrier protein KLH (keyhole limpet hemocyanin) was studied extensively in animal models of arthritis and in several clinical trials. TNF-K vaccine induced the generation of anti-human TNF- $\alpha$ antibodies that didn't cross react with mouse TNF- $\alpha$. Transgenic mice expressing human TNF- $\alpha$ (TTG mice) were a suitable model of arthritis to evaluate the efficacy of TNF-K vaccine. In this model, TNF-K vaccine resulted in the production of anti-TNF- $\alpha$ neutralizing antibodies that protected mice against established arthritis (Le Buanec et al., 2006). Anti-TNF- $\alpha$ antibody production was reversible and could not be stimulated by TNF- $\alpha$ administration, as this approach did not induce any cellular-mediated immunity against TNF- $\alpha$. Therapeutic antibody production was not altered by methotrexate co-administration and the protective effect was correlated with the levels of anti-TNF- $\alpha$ antibody 
production in sera of vaccinated mice. TNF-K efficacy was compared to infliximab in TTG mice and showed a delay before arthritis inhibition linked to the induction of therapeutic antibodies. This delay did not induce significant alterations of the paws versus infliximab-treated mice, and could not be reduced by simultaneous administration of infliximab in mice during TNF-K vaccination. Indeed, co-administration of TNF-K and infliximab led to a lower response to the vaccine, probably due to epitope masking: TNF-K being constituted with the full human cytokine, infliximab could recognize TNF- $\alpha$, and increase the clearance of the vaccine. Experiments in animal models of Listeria monocytogenes and Mycobacterium tuberculosis recently shown that mice vaccinated with a TNF conjugate did not develop a hypersensitivity to these infections (Assier et al., 2016). A first clinical trial (phase IIa) was conducted with RA patients who previously experienced secondary failure of TNF$\alpha$ inhibitors. Several doses of TNF-K and different schedules of administration were used in order to give rise to therapeutic anti-TNF- $\alpha$ antibodies (Durez et al., 2014). TNF-K vaccine was well tolerated and this first trial held promising clinical improvements. However, a second clinical trial (phase IIB/II) conducted with a larger panel of RA patients did not reach significant therapeutic benefits. This failure could be due to the absence of detection of neutralizing anti-TNF- $\alpha$ antibodies in sera of patients.

Similarly to anti-TNF studies, several anti-cytokine vaccination approaches were developed in autoimmune models against different cytokines including IL-1 $\beta$ (Table 1). These vaccines were composed either with entire cytokine or peptide of cytokine, linked to various carrier proteins (KLH, VLP, Ova, DTT). The use of the full cytokine to compose a vaccine presents some limitations. The cost of recombinant purified cytokines is high and their use induces a polyclonal antibody response against all exposed epitopes. Among these antibodies, only a variable proportion will exert neutralizing capacities and there is a potential risk of unwanted reaction against a shared epitope.

The use of peptide of cytokine allows limiting antibody generation to selected epitopes. In return, the conformation and the peptidic sequence of the cytokine that interact with the receptor have to be determined. Peptides are often selected in interacting zone of cytokine with its receptor in order to block this interaction. Beyond this highest potential selectivity, the cost of peptides is lower and could lead to similar protections than its entire cytokine counterpart. In this sense, VEGF neutralization by both vaccinal approaches was studied in the collagen-induced arthritis (CIA) model. Vaccines were either constituted by the full length mouse VEGF-A or a peptide (Vpep1) selected in the sequence of VEGF-A, linked to the carrier protein KLH. Vpep1 was chosen for its potential interaction with the VEGF-A co-receptor Neuropilin-1, implied in pathologic angiogenesis. Both types of VEGF vaccines led to the production of anti-VEGF polyclonal neutralizing antibodies. Clinical and histological scores of inflammation and destruction were reduced as well as synovial vascularization (Semerano et al., 2016b). Thus, restraining antibody response to a single peptide sequence with a peptide vaccine could protect immunized mice from arthritis.
The use of peptides of cytokine could be also an asset when cytokine are composed of two chains that could be shared with other cytokines. A vaccinal approach against IL-23 was conducted with peptides chosen in the IL-23p19 subunit. IL23 is important for the generation of Th17 lymphocytes that are implied in autoimmune diseases. IL-23 is constituted by the IL-12p40 subunit, shared with IL-12, and the specific IL23 p19 subunit. Because IL-12 and IL-23 could have opposite effects in autoimmune models, it was of great importance to inhibit selectively IL-23. In this context, two different teams have conducted experiments in CIA and colitis models. The first vaccine constituted by IL-23p19 peptides linked to KLH was protective in CIA model, whereas the second constituted by IL23 p19 peptides fused to hepatitis B core antigen was protective in colitis.

\section{TARGETING IL-1 IN CHRONIC DISEASES}

IL-1 is a major inflammatory cytokine that act at the systemic and local levels (Cavalli and Dinarello, 2015). IL-1 is encoded by two distinct genes giving rise to two related but functionally distinct proteins: IL- $1 \alpha$ and IL- $1 \beta$ that interact with two IL-1 receptors. IL-1R2, as a decoy receptor, binds to IL-1 but does not transmit a signal. Signaling is assumed by IL-1R1 that is expressed on the surface of most cell types. IL- $1 \alpha$ and IL-1 $\beta$ are primarily expressed as precursors. IL-1 $\alpha$ precursor could be release from necrotic cells in a fully active form. Thus, IL- $1 \alpha$ acts as an alarmin and could induce sterile inflammation. By contrast, IL- $1 \beta$ precursor is inactive and need to be cleaved to become active. Several enzymes are implied, as proteinase- 3 and elastase from neutrophils or caspase- 1 from hematopoietic cells. In other cells, caspase-1 exists as a pro-enzyme that needs to be cleaved by a macromolecular complex named the inflammasome. NLRP3 (also known as cryopyrin) is one of the major component of inflammasome. Mutations leading to a gain of function of NLRP3 protein are associated with high amounts of IL- $1 \beta$ secretion and autoinflammatory diseases.

In brief, IL- $1 \alpha$ is expressed locally, whereas IL- $1 \beta$ is expressed at the systemic level and in inflamed sites as synovial fluids in rheumatoid arthritis or gouty arthritis (McInnes and Schett, 2007; Richette and Bardin, 2010). IL-1 $\alpha$ and IL-1 $\beta$ binding could be limited by the naturally occurring inhibitor IL-1 receptor antagonist (IL-1Ra). IL-1Ra can bind to IL-1 receptor with greater affinity than either IL- $1 \alpha$ or IL-1 $\beta$. A recombinant version of IL-1Ra (anakinra) was developed, but its therapeutic use is limited by its short-lived effect leading to frequent injections to the patient. Two other IL-1 blockers were developed and present lower clearance rates. Rilonacept is a soluble decoy receptor that inhibits primarily IL- $1 \beta$, but also IL- $1 \alpha$, and canakinumab is a monoclonal antibody that neutralizes specifically IL- $1 \beta$.

It was suggested that specific targeting of IL-1 $\beta$, may be beneficial over systemic IL-1 blockade. As an example, canakinumab was effective for the treatment of acute gouty arthritis, whereas rilonacept was not. In animal models, several studies targeting IL- $1 \alpha$ and IL- $1 \beta$ by a vaccinal approach reinforce this hypothesis. Vaccines were obtained by linking mouse or human IL-1 cytokines to Virus Like Particles (VLPs). 
TABLE 1 | Applications of anti-cytokine vaccinations in autoimmune diseases.

\begin{tabular}{|c|c|c|c|c|c|}
\hline Cytokine target & Product & Diseases & Animal species & References & Clinical trial \\
\hline $\mathrm{mlL}-1 \beta$ & Mouse IL-1 $\beta$ peptides/KLH & Arthritis & Mouse & Bertin-Maghit et al., 2005 & Pre-clinical \\
\hline $\mathrm{mlL}-1(\alpha$ and $\beta)$ & Mouse IL-1 $\alpha / \mathrm{IL}-1 \beta / \mathrm{VLP}$ & Arthritis & Mouse & Spohn et al., 2008 & Pre-clinical \\
\hline $\mathrm{hlL}-1 \beta$ and $\mathrm{mlL}-1 \beta$ & Human and murine IL-1 $\beta / V L P$ & Type 2 Diabetes & Mouse & Spohn et al., 2014 & Pre-clinical \\
\hline hIL-1 $\beta$ & Human IL-1 $\beta / V L P$ & Type 2 Diabetes & Human & Cavelti-Weder et al., 2016 & Phase I \\
\hline \multirow[t]{3}{*}{ mlL-6 } & Modified mouse IL-6 & Arthritis, MS & Mouse & Galle et al., 2007 & Pre-clinical \\
\hline & Mouse IL-6 peptide/KLH & SSc & Mouse & Desallais et al., 2014 & Pre-clinical \\
\hline & Mouse IL-6 peptide/KLH & DTH & Monkey & Desallais et al., 2016 & Pre-clinical \\
\hline hlL-15 & Modified human IL-15 & Arthritis & Monkey & Rodríguez-Álvarez et al., 2016 & Pre-clinical \\
\hline \multirow[t]{3}{*}{$\mathrm{mlL}-17 \mathrm{~A}$} & Mouse IL-17A/Ova & MS & Mouse & Uyttenhove and Van Snick, 2006 & Pre-clinical \\
\hline & Mouse IL-17ANLP & Arthritis, MS & Mouse & Röhn et al., 2006 & Pre-clinical \\
\hline & Mouse IL-17ANLP & $\begin{array}{l}\text { Autoimmune } \\
\text { Myocarditis }\end{array}$ & Mouse & Sonderegger et al., 2006 & Pre-clinical \\
\hline mlL-18 & Mouse IL-18 plasmid & SLE & Mouse & Bossù et al., 2003 & Pre-clinical \\
\hline \multirow[t]{2}{*}{ mlL-23 } & Mouse IL-23p19 peptide/KLH & Arthritis & Mouse & Ratsimandresy et al., 2011 & Pre-clinical \\
\hline & Mouse IL-23p19 peptide/HBc Ag & Chronic Colitis & Mouse & Guan et al., 2013 & Pre-clinical \\
\hline \multirow[t]{4}{*}{ hIFN- $\alpha$} & Human IFN- $\alpha / \mathrm{KLH}$ & SLE & Hum. Transg. Mouse & Zagury et al., 2009 & Pre-clinical \\
\hline & Human IFN- $\alpha / \mathrm{KLH}$ & SLE & Hum. Transg. Mouse & Mathian et al., 2011 & Pre-clinical \\
\hline & Human IFN- $\alpha / \mathrm{KLH}$ & SLE & Human & Lauwerys et al., 2013 & Phase I/II \\
\hline & Human IFN- $\alpha / \mathrm{KLH}$ & SLE & Human & Ducreux et al., 2016 & Phase I/II \\
\hline \multirow[t]{6}{*}{ hTNF- $\alpha$} & Human TNF- $\alpha / \mathrm{KLH}$ & Arthritis & Hum. Transg. Mouse & Le Buanec et al., 2006 & Pre-clinical \\
\hline & & Arthritis & Hum. Transg. Mouse & Delavallée et al., 2008 & Pre-clinical \\
\hline & & Arthritis & Hum. Transg. Mouse & Biton et al., 2011 & Pre-clinical \\
\hline & & Arthritis & Mouse & Assier et al., 2012 & Pre-clinical \\
\hline & & Arthritis & Hum. Transg. Mouse & Semerano et al., 2013 & Pre-clinical \\
\hline & & Arthritis & Human & Durez et al., 2014 & Phase lla \\
\hline \multirow[t]{7}{*}{ mTNF- $\alpha$} & Modified mouse TNF- $\alpha$ & Arthritis, Cachexia & Mouse & Dalum et al., 1999 & Pre-clinical \\
\hline & Human TNF- $\alpha$ plasmid & Arthritis & Mouse & Shen et al., 2007 & Pre-clinical \\
\hline & Mouse TNF- $\alpha$ peptide/VLP & Arthritis & Mouse & Chackerian et al., 2001 & Pre-clinical \\
\hline & Mouse TNF- $\alpha / T N F-\alpha$ peptide/VLP & Arthritis, Infections & Mouse & Spohn et al., 2007 & Pre-clinical \\
\hline & Mouse TNF- $\alpha$ peptide/KLH & Septic shock & Mouse & Capini et al., 2004 & Pre-clinical \\
\hline & Mouse TNF- $\alpha$ peptide/KLH & Arthritis & Mouse & Sun et al., 2016 & Pre-clinical \\
\hline & Mouse TNF- $\alpha$ peptide/DTT & Arthritis & Mouse & Zhang et al., 2016 & Pre-clinical \\
\hline rTNF- $\alpha$ & Rat TNF- $\alpha$ plasmid & Arthritis & Rat & Wildbaum et al., 2000 & Pre-clinical \\
\hline mVEGF-A & Mouse VEGF/VEGF peptide/KLH & Arthritis & Mouse & Semerano et al., 2016b & Pre-clinical \\
\hline
\end{tabular}

DTH, delayed-type hypersensitivity; DTT, transmembrane domain of diphtheria toxin; MS, multiple sclerosis; HBc Ag, hepatitis B core antigen; KLH, keyhole limpet hemocyanin; SLE, systemic lupus erythematosus; SSc, systemic sclerosis; VLP, virus-like particles.

These compounds led to high production of anti-IL- $1 \alpha$ or antiIL- $1 \beta$ neutralizing antibodies by vaccinated mice. In the CIA model, both type of vaccines conduct to a higher protection against arthritis than daily administration of mouse IL-1Ra. In a second model of arthritis, the Collagen Antibody-Induced Arthritis model (CAIA), immunization with the IL- $1 \beta$ vaccine protects strongly against arthritis, whereas anti-IL-1 $\alpha$ vaccine has no effect (Spohn et al., 2008). IL-1 $\beta$ vaccine was shown to be also effective in a type 2 diabetes model, and its human counterpart was well tolerated in a phase I clinical trial in patients with type 2 diabetes (Cavelti-Weder et al., 2016). In another study, IL-1 $\beta$ was specifically targeted by vaccines constituted 
by peptides of IL- $1 \beta$ linked to KLH. Peptide sequences were chosen in regions interacting with the receptor and led to the generation of neutralizing anti-IL-1 $\beta$ antibodies. One IL$1 \beta$ vaccine showed a protective effect in the CIA model on clinical and histological signs of inflammation (Bertin-Maghit et al., 2005). Thus, selective inhibition of IL- $1 \beta$ gave promising results and could be achieved with a peptide-based vaccine. However, targeting IL-1 or its receptor remains an unresolved issue, with contrasting animal and in vitro data arguing in favor of either specific cytokine or receptor blockade, but no conclusion that is relevant to the clinical use of these agents.

\section{CANDIDATES FOR A VACCINE TARGETING IL-1}

The best candidates are chronic diseases with flares, IL-1 dependent, and showing some improvement in previous clinical trials with currently used anti-IL-1 treatments. The low cost

\section{REFERENCES}

Assier, E., Belmellat, N., Semerano, L., Ryffel, B., Decker, P., Quesniaux, V., et al. (2016). Anti-TNF vaccination protects from experimental Arthritis without affecting resistance to Mycobacterium tuberculosis or Listeria monocytogenes infection [abstract]. Arthritis Rheumatol. 68(Suppl. 10). Available online at: http://acrabstracts.org/abstract/anti-tnf-vaccinationprotects-from-experimental-arthritis-without-affecting-resistance-to-myco bacterium-tuberculosis-or-listeria-monocytogenes-infection/

Assier, E., Semerano, L., Duvallet, E., Delavallée, L., Bernier, E., Laborie, M., et al. (2012). Modulation of anti-tumor necrosis factor alpha (TNF- $\alpha$ ) antibody secretion in mice immunized with TNF- $\alpha$ kinoid. Clin. Vaccine Immunol. 19, 699-703. doi: 10.1128/CVI.05649-11

Bertin-Maghit, S. M., Capini, C. J., Bessis, N., Chomilier, J., Muller, S., Abbas, A., et al. (2005). Improvement of collagen-induced arthritis by active immunization against murine IL-1beta peptides designed by molecular modelling. Vaccine 22, 3144-3153. doi: 10.1016/j.vaccine.2005.03.030

Biton, J., Semerano, L., Delavallée, L., Lemeiter, D., Laborie, M., GrouardVogel, G., et al. (2011). Interplay between TNF and regulatory $\mathrm{T}$ cells in a TNF-driven murine model of arthritis. J. Immunol. 186, 3899-3910. doi: $10.4049 /$ jimmunol.1003372

Bossù, P., Neumann, D., Del Giudice, E., Ciaramella, A., Gloaguen, I., Fantuzzi, G., et al. (2003). IL-18 cDNA vaccination protects mice from spontaneous lupus-like autoimmune disease. Proc. Natl. Acad. Sci. U.S.A. 100, 14181-14186. doi: 10.1073/pnas.2336094100

Capini, C. J., Bertin-Maghit, S. M., Bessis, N., Haumont, P. M., Bernier, E. M., Muel, E. G., et al. (2004). Active immunization against murine TNFalpha peptides in mice: generation of endogenous antibodies crossreacting with the native cytokine and in vivo protection. Vaccine 22, 3144-3153. doi: 10.1016/j.vaccine.2004.01.064

Cavalli, G., and Dinarello, C. A. (2015). Treating rheumatological diseases and comorbidities with interleukin-1 blocking therapies. Rheumatology (Oxford) 54, 2134-2144. doi: 10.1093/rheumatology/kev269

Cavelti-Weder, C., Timper, K., Seelig, E., Keller, C., Osranek, M., Lässing, U., et al. (2016). Development of an Interleukin-1 $\beta$ vaccine in patients with Type 2 Diabetes. Mol. Ther. 24, 1003-1012. doi: 10.1038/mt.2015.227

Chackerian, B., Lowy, D. R., and Schiller, J. T. (2001). Conjugation of a self-antigen to papillomavirus-like particles allows for efficient induction of protective autoantibodies. J. Clin. Invest. 108, 415-423. doi: 10.1172/JCI11849

Dalum, I., Butler, D. M., Jensen, M. R., Hindersson, P., Steinaa, L., Waterston, A. M., et al. (1999). Therapeutic antibodies elicited by immunization against TNF-alpha. Nat. Biotechnol. 17, 666-669. doi: 10.1038/10878 of development could allow treatments of patients in Southern countries, where access to healthcare is a concern for most of people. Research on vaccination targeting IL-1 $1 \beta$ is still ongoing. Preclinical studies with a peptide-based vaccine targeting IL-1 $\beta$ are currently focused on carrier protein and adjuvant, and clinical studies are planned. The use of vaccination targeting IL-1 extends now from initial rheumatic diseases, such as RA and crystalinduced arthritis (such as gout or acute chondrocalcinosis), to autoinflammatory diseases, such as systemic juvenile idiopathic arthritis (JIA), cryopyrin-associated periodic syndromes (CAPS), and familial Mediterranean fever (FMF). IL-1 inhibitors are also promising in two highly prevalent inflammatory diseases, encountered as co-morbidities in patients with rheumatic diseases, namely arteriosclerosis and type 2 diabetes.

\section{AUTHOR CONTRIBUTIONS}

$\mathrm{EA}$ and $\mathrm{MB}$ draft the manuscript. $\mathrm{NB}$ and $\mathrm{JZ}$ revised the manuscript.

Delavallée, L., Le Buanec, H., Bessis, N., Assier, E., Denys, A., Bizzini, B., et al. (2008). Early and long-lasting protection from arthritis in tumour necrosis factor alpha $(\mathrm{TNF} \alpha)$ transgenic mice vaccinated against TNFalpha. Ann. Rheum. Dis. 67, 1332-1338. doi: 10.1136/ard.2007.079137

Desallais, L., Avouac, J., Fréchet, M., Elhai, M., Ratsimandresy, R., Montes, M., et al. (2014). Targeting IL- 6 by both passive or active immunization strategies prevents bleomycin-induced skin fibrosis. Arthritis Res. Ther. 16:R157. doi: 10.1186/ar4672

Desallais, L., Bouchez, C., Mouhsine, H., Moreau, G., Ratsimandresy, R., Montes, M., et al. (2016). Immunization against an IL-6 peptide induces anti-IL-6 antibodies and modulates the delayed-type hypersensitivity reaction in cynomolgus monkeys. Sci. Rep. 6:19549. doi: 10.1038/srep 19549

Ducreux, J., Houssiau, F. A., Vandepapelière, P., Jorgensen, C., Lazaro, E., Spertini, F., et al. (2016). Interferon $\alpha$ kinoid induces neutralizing anti-interferon $\alpha$ antibodies that decrease the expression of interferon-induced and B cell activation associated transcripts: analysis of extended follow-up data from the interferon $\alpha$ kinoid phase I/II study. Rheumatology (Oxford) 55, 1901-1905. doi: $10.1093 /$ rheumatology/kew262

Durez, P., Vandepapeliere, P., Miranda, P., Toncheva, A., Berman, A., Kehler, T., et al. (2014). Therapeutic vaccination with TNF-Kinoid in TNF antagonistresistant rheumatoid arthritis: a phase II randomized, controlled clinical trial. PLoS ONE 9:e113465. doi: 10.1371/journal.pone.0113465

Galle, P., Jensen, L., Andersson, C., Cuzzocrea, S., Di Paola, R., Nicoletti, F., et al. (2007). Vaccination with IL-6 analogues induces autoantibodies to IL-6 and influences experimentally induced inflammation. Int. Immunopharmacol. 7, 1704-1713. doi: 10.1016/j.intimp.2007.08.026

Guan, Q., Burtnick, H. A., Qing, G., Weiss, C. R., Ma, A. G., Ma, Y., et al. (2013). Employing an IL-23 p19 vaccine to block IL-23 ameliorates chronic murine colitis. Immunotherapy 5, 1313-1322. doi: 10.2217/imt.13.141

Lauwerys, B. R., Hachulla, E., Spertini, F., Lazaro, E., Jorgensen, C., Mariette, X., et al. (2013). Down-regulation of interferon signature in systemic lupus erythematosus patients by active immunization with interferon $\alpha$-kinoid. Arthritis Rheum. 65, 447-456. doi: 10.1002/art.37785

Le Buanec, H., Delavallée, L., Bessis, N., Paturance, S., Bizzini, B., Gallo, R., et al. (2006). TNFalpha kinoid vaccination-induced neutralizing antibodies to $\mathrm{TNF} \alpha$ protect mice from autologous TNFalpha-driven chronic and acute inflammation. Proc. Natl. Acad. Sci. U.S.A. 103, 19442-19447. doi: 10.1073 /pnas.0604827103

Mathian, A., Amoura, Z., Adam, E., Colaone, F., Hoekman, M. F., Dhellin, O., et al. (2011). Active immunisation of human interferon $\alpha$ transgenic mice with a human interferon $\alpha$ Kinoid induces antibodies that neutralise interferon $\alpha$ 
in sera from patients with systemic lupus erythematosus. Ann. Rheum. Dis. 70, 1138-1143. doi: 10.1136/ard.2010.141101

McInnes, I. B., and Schett, G. (2007). Cytokines in the pathogenesis of rheumatoid arthritis. Nat. Rev. Immunol. 7, 429-442. doi: 10.1038/nri2094

Ratsimandresy, R. A., Duvallet, E., Assier, E., Semerano, L., Delavallée, L., Bessis, N., et al. (2011). Active immunization against IL-23p19 improves experimental arthritis. Vaccine 29, 9329-9336. doi: 10.1016/j.vaccine.2011.09.134

Richette, P., and Bardin, T. (2010). Gout. Lancet 375, 318-328. doi: 10.1016/S0140-6736(09)60883-7

Rodríguez-Álvarez, Y., Morera-Díaz, Y., Gerónimo-Pérez, H., Castro-Velazco, J., Martínez-Castillo, R., Puente-Pérez, P., et al. (2016). Active immunization with human interleukin-15 induces neutralizing antibodies in non-human primates. BMC Immunol. 17:30. doi: 10.1186/s12865-016-0168-6

Röhn, T. A., Jennings, G. T., Hernandez, M., Grest, P., Beck, M., Zou, Y., et al. (2006). Vaccination against IL-17 suppresses autoimmune arthritis and encephalomyelitis. Eur. J. Immunol. 36, 2857-2867. doi: 10.1002/eji.200636658

Semerano, L., Assier, E., and Boissier, M. C. (2012). Anti-cytokine vaccination: a new biotherapy of autoimmunity? Autoimmun. Rev. 11, 785-786. doi: 10.1016/j.autrev.2012.02.003

Semerano, L., Biton, J., Delavallée, L., Duvallet, E., Assier, E., Bessis, N., et al. (2013). Protection from articular damage by passive or active anti-tumour necrosis factor (TNF)- $\alpha$ immunotherapy in human TNF- $\alpha$ transgenic mice depends on anti-TNF- $\alpha$ antibody levels. Clin. Exp. Immunol. 172, 54-62. doi: $10.1111 /$ cei. 12040

Semerano, L., Duvallet, E., Belmellat, N., Marinval, N., Schall, N., Monteil, M., et al. (2016b). Targeting VEGF-A with a vaccine decreases inflammation and joint destruction in experimental arthritis. Angiogenesis 19, 39-52. doi: 10.1007/s10456-015-9487-0

Semerano, L., Minichiello, E., Bessis, N., and Boissie, M. C. (2016a). Novel immunotherapeutic avenues for rheumatoid arthritis. Trends Mol. Med. 22, 214-229. doi: 10.1016/j.molmed.2016.01.005

Shen, Y., Chen, J., Zhang, X., Wu, X., and Xu, Q. (2007). Human TNFalpha gene vaccination prevents collagen-induced arthritis in mice. Int. Immunopharmacol. 7, 1140-1149. doi: 10.1016/j.intimp.2007.04.009

Sonderegger, I., Röhn, T. A., Kurrer, M. O., Iezzi, G., Zou, Y., Kastelein, R. A., et al. (2006). Neutralization of IL-17 by active vaccination inhibits IL23-dependent autoimmune myocarditis. Eur. J. Immunol. 36, 2849-2856. doi: 10.1002/eji.200636484

Spohn, G., Guler, R., Johansen, P., Keller, I., Jacobs, M., Beck, M., et al. (2007). A virus-like particle-based vaccine selectively targeting soluble TNF-alpha protects from arthritis without inducing reactivation of latent tuberculosis. $J$. Immunol. 178, 7450-7457. doi: 10.4049/jimmunol.178.11.7450

Spohn, G., Keller, I., Beck, M., Grest, P., Jennings, G. T., and Bachmann, M. F. (2008). Active immunization with IL-1 displayed on virus-like particles protects from autoimmune arthritis. Eur. J. Immunol. 38, 877-887. doi: 10.1002/eji.200737989

Spohn, G., Schori, C., Keller, I., Sladko, K., Sina, C., Guler, R., et al. (2014) Preclinical efficacy and safety of an anti-IL-1 $\beta$ vaccine for the treatment of type 2 diabetes. Mol. Ther. Methods Clin. Dev. 1:14048. doi: 10.1038/mtm.2014.48

Sun, J. H., Zhang, Y. H., Kuang, J. Y., Liu, G., Liu, Y. X., and Liu, B. H. (2016). Active immunisation targeting soluble murine tumour necrosis factor alpha is safe and effective in collagen-induced arthritis model treatment. Clin. Exp. Rheumatol. 34, 242-246.

Uyttenhove, C., and Van Snick, J. (2006). Development of an anti-IL-17A autovaccine that prevents experimental auto-immune encephalomyelitis. Eur. J. Immunol. 36, 2868-2874. doi: 10.1002/eji.200636662

Wildbaum, G., Youssef, S., and Karin, N. (2000). A targeted DNA vaccine augments the natural immune response to self TNF-alpha and suppresses ongoing adjuvant arthritis. J. Immunol. 165, 5860-5866. doi: 10.4049/jimmunol.165.10.5860

Zagury, D., Le Buanec, H., Mathian, A., Larcier, P., Burnett, R., Amoura, Z., et al. (2009). IFNalpha kinoid vaccine-induced neutralizing antibodies prevent clinical manifestations in a lupus flare murine model. Proc. Natl. Acad. Sci. U.S.A. 106, 5294-5299. doi: 10.1073/pnas.0900615106

Zhang, L., Wang, J., Xu, A., Zhong, C., Lu, W., Deng, L., et al. (2016). A rationally designed TNF- $\alpha$ epitope-scaffold immunogen induces sustained antibody response and alleviates collagen-induced arthritis in mice. PLoS ONE 11:e0163080. doi: 10.1371/journal.pone. 0163080

Conflict of Interest Statement: EA and NB have no disclosure. JZ is shareholder of the company Peptinov. MB and JZ have received a Grant from the French Ministries of Research and Industries (FUI) for the development of anti-IL1 peptide vaccination.

Copyright (C) 2017 Assier, Bessis, Zagury and Boissier. This is an open-access article distributed under the terms of the Creative Commons Attribution License (CC BY). The use, distribution or reproduction in other forums is permitted, provided the original author(s) or licensor are credited and that the original publication in this journal is cited, in accordance with accepted academic practice. No use, distribution or reproduction is permitted which does not comply with these terms. 